\title{
クロムスピネルの化学組成から推察する東北地方の 小規模超苦鉄質岩体のテクトニクス
}

\author{
Tectonics of small ultramafic bodies in Northeast Japan, inferred from chemical \\ composition of chromian spinels
}

\author{
町田 怜史(Satoshi MACHIDA)*,** \\ 石渡 明(Akira ISHIWATARI) $)^{* * *}$
}

\begin{abstract}
Petrography and relic spinel chemistry of small ultramafic bodies disseminated in the northeastern Honshu Island, Japan are studied at Wakasennin, Yakeishidake, Motai, Kawatabi, Kinkasan, Marumori and Surikami from north to south, in comparison with the large, well studied large ultramafic bodies at Hayachine and Miyamori in the South Kitakami terrain. Ultramafic rocks from Kinkasan contain olivine, and those from Marumori and Surikami bear both olivine and orthopyroxene, but others are completely serpentinized. However, chromian spinels commonly survive in their cores. Chromian spinels from the northern areas (Wakasennin, Yakeishidake, Motai, Kinkasan) are highly chromian (Cr\#0.65-0.90), implying their origin in arc-related depleted mantle. However, chromian spinels from Marumori and Surikami show relatively low $\mathrm{Cr} \#(0.35-0.65)$, implying their origin in an arc-related, relatively fertile mantle. These Cr-rich and -poor spinels are both present in the Hayachine and Miyamori bodies. However, chromian spinels from Kawatabi show a unique, higher-Mg\# trend in the $\mathrm{Cr} \#-\mathrm{Mg} \#$ diagram, and this provides the first identification of provenance for the high Mg\# detrital chromian spinels reported from the Lower Jurassic Shizugawa Group in the South Kitakami terrain. Analogous high-Mg\# spinels are known from anhydrous peridotites from the Mariana forearc. Comparison with the reported spinels from the Carboniferous conglomerate of the Nedamo zone indicates that the erosion of these ultramafic bodies started as early as the Carboniferous time. The difference in spinel chemistry between the Abukuma (Surikami) and Kitakami (other bodies) terrains is not significant, indicating pervasive exposure of the Early Paleozoic Hayachine-Miyamori forearc ophiolites in the Late PaleozoicMesozoic forearc areas of Northeast Japan, including the Abukuma terrain.
\end{abstract}

Keywords: Hayachine, Miyamori, Kawatabi, Island arc, Forearc, Ordovician Early Paleozoic, Northeast Japan, Olivine

\section{I. はじめに}

東北地方には，南部北上帯北部の早池峰と宮守にそれぞ れ長さ 10-20 km のオフィオライト岩体が存在し, 両岩体 は超苦鉄質岩とはんれい岩, 角閃石岩, ドレライトなどか
らなる(Ozawa, 1984; Fujimaki and Yomogida, 1986a, 1986b; Onuki, 1963，1965)。宮守地域のはんれい岩中の角 閃石からは 421-484 Maの $\mathrm{K}-\mathrm{Ar}$ 年代が報告されており (小沢ら，1988）, 北上山地のオフィオライトは大江山オ フィオライトと並んで日本最古の古生代前期, オルドビス

doi: $10.2465 /$ gkk. 120509

(平成 24 年 5 月 9 日受付, 平成 24 年 12 月 18 日受理, 平成 25 年 2 月 14 日早期公開)

* 東北大学大学院理学研究科地学専攻, $=980-8578$ 宮城県仙台市青葉区荒巻字青葉 6-3

** 現所属 : 住鉱資源開発株式会社, 干110-0008 東京都台東区池之端 2-9-7

*** 東北大学東北アジア研究センター, ₹980-8576 宮城県仙台市青葉区川内 41 番地

* Department of Earth Science, Graduate School of Science, Tohoku University, 6-3 Aramaki-Aza Aoba-ku, Sendai, Miyagi 9808578, Japan

** Present address: Sumiko Resources Exploration \& Development Co., Ltd 9-7, Ikenohata 2-Chome, Taito-Ku, Tokyo 110-0008, Japan

*** Center for Northeast Asian Studies, Tohoku University, 41 Kawauchi, Aoba, Sendai Miyagi 980-8576, Japan E-mail: geoishw@ cneas.tohoku.ac.jp 
紀のオフィオライトと考えられている(石渡，1989）。ま た，超苦鉄質岩中の角閃石の存在とその化学組成から，両 岩体は島弧下で形成されたと考えられている(Ozawa, 1988，1994)。しかし, 早池峰・宮守以外にも, 長さ数 $\mathrm{km}$ 以下の小規模な超苦鉄質岩類は脊梁山脈や阿武隈高原など 東北地方各地に点在し, 和賀仙人(蟹沢, 1969), 焼石岳 （北村， 1965 ; 北村 - 蟹沢，1971), 母体(島津, 1954a, 1954b ; 前川, 1981)，步渡(青木，1972；土谷ら，1997)，金華 山(滝沢ら，1974), 丸森 (青木 - 船山, 1982 ; 藤田ら, 1988), 摺上(八島ら，1982)などが知られている。しか し, これら小規模岩体の岩石学的性質に関する総括的な研 究はなかった。

一方, 南部北上帯のジュラ系志津川層群の砂岩 (竹内, 1994) や根田茂帯 (永広 · 鈴木, 2003) の石炭紀付加体中の 礫岩 (Uchino and Kawamura, 2010)中のスピネル砕屑粒子 の化学組成が報告されており, 宮守・早池峰のものと比較 して議論されてきたが, 宮守・早池峰にはない $\mathrm{Mg}$ に富む スピネルなども報告されており，それらの供給源を明らか にするためにも小規模岩体の広域的な調査が必要であった。 小論では, これら東北地方に散在する小規模超苦鉄質岩
体の産状, 記載岩石学的性質, スピネル化学組成を報告 し, 早池峰- 宮守両岩体との類似点及び相違点, 阿武隈帯 と北上帯の超苦鉄質岩の違い, 周辺の古生代 - 中生代の地 層中から報告されている砕屑性クロムスピネルとの対応関 係について考察し，そのテクトニクスを論じる。

\section{II. 地質各論}

本研究の調査地域は北から和賀仙人, 焼石岳, 母体, 川 渡，金華山，丸森，摺上である (Fig. 1)。このうち, 北上 帯々阿武隈帯の花崗岩類, 変成岩類の境界々される畑川構 造線およびその延長の鬼首湯沢マイロナイト帯(久保・山 元， 1990 ; 笹田，1985）より西側に位置するのは摺上だけ で, これは资梁山脈中の阿武郎帯である。丸森は畑川構造 線とその東側に並行する双葉構造線の間に位置し阿武隈高 原中の北上帯である。他は全て北上山地または脊梁山脈中 で北上帯に属する。

\section{1. 和賀仙人}

岩手県北上市西部および西和賀町東部の和賀仙人周辺で は堆積岩, 変成岩類が分布し, 特に和賀仙人西方の当楽沢 には, 北 $100 \mathrm{~m}$, 東西 $200 \mathrm{~m}$ の範囲に黒色粘板岩, 黒雲母

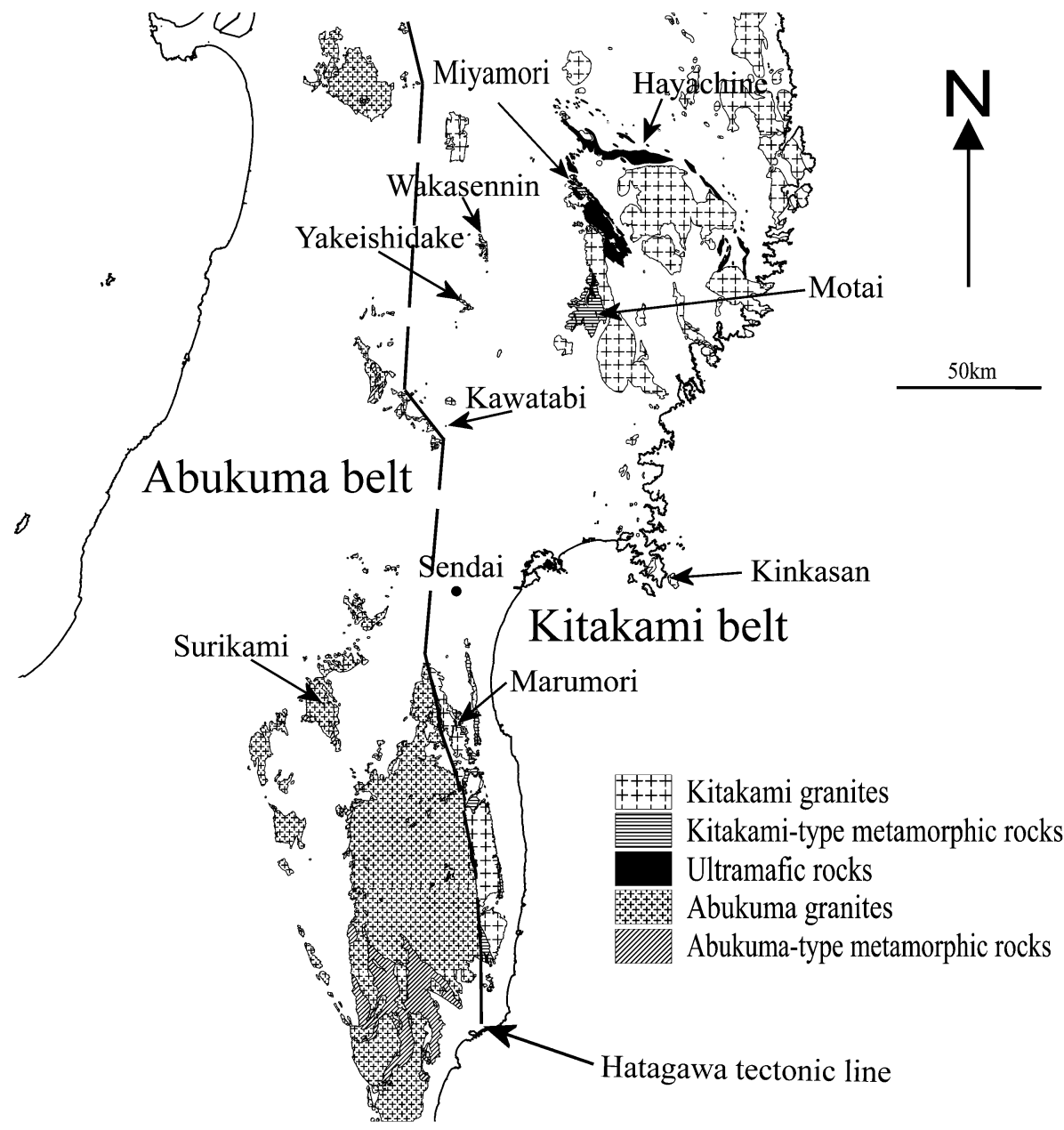

Fig. 1. Index map showing the location of the studied ultramafic rocks in Northeast Japan. 
片岩を主体として角閃岩, 石灰岩などが分布し, 白亜紀花 崗岩類によって貫かれている(大沢ら，1971; Minato et. $a l .$, 1979)。また，蟹沢(1969) は，石英一絹雲母一緑泥石 一曹長石片岩がホルンフェルス化したものを主体とし，接 触变成を受けた石灰岩や蛇紋岩化した超苦鉄質岩類を伴う と報告している。今回は角閃岩の構造的下位に位置する超 苦鉄質岩の転石を当楽沢でサンプリングした。

\section{2. 焼石岳}

岩手県奥州市西部の焼石岳南麓の胆沢川沿いでは, 東西 約 $2 \mathrm{~km}$ 南北 $2 \mathrm{~km}$ の範囲で下部に絹雲母石英片岩 (椿山橋 層), 上部に角閃岩抢よび角閃石片岩 (上の倉沢層)が分布 し, 時に粘板岩由来の黒雲母ホルンフェルスを夾在し, 超 苦鉄質岩が断層に沿って定置している(北村·蟹沢, 1971)。このほか, 珪長質片岩, 泥質片岩, 粘板岩もあ り，これらを石英閃緑岩と花崗閃緑岩が貫いて上の倉鉛 · 亜鉛鉱床を形成した(北村, 1965)。そしてこれらは新第三 系及び第四系の火山岩類に覆われている。超苦鉄質岩は胆 沢川と小出川の合流点から下流に分布し, それらを露頭か らサンプリングした。

\section{3. 母体}

岩手県奥州市東部抢よび一関市北東部母体地域の超苦鉄 質岩類は島津 (1954a，1954b) によって研究された。その 後, それらを含む母体層群は, 蛇紋岩, はんれい岩, 角閃 岩, 玄武岩などのオフィオライト岩類のブロック（オリス トリス）と砂質岩・泥質岩の基質からなるオリストスト ロームが後生的に低温高圧型の変成作用を受けたものと考 えられた(前川, 1981)。超苦鉄質岩は蛇紋岩化していて, 変はんれい岩等と複合岩体を形成する場合がある。本研究 で扱った蛇紋岩は奥州市水沢区黒石寺正法寺沢の露頭から 採取した。

\section{4. 川渡}

宮城県大崎市西部川渡に超苦鉄質岩が産し，新第三系の 凝死岩, 第四系の火砕流堆積物や扇状地堆積物に被われて いる(青木, 1972 ; 土谷ら, 1997)。東北大学農場北部の沢 沿いの東西 $60 \mathrm{~m}$, 南北 $40 \mathrm{~m}$ の範囲の露頭からサンプリン グした。原岩はかんらん岩と思われるが，その種類は特定 できず，他の古期岩類との関係も不明である。

\section{5. 金華山}

宮城県石巻市東部の北上山地最南端金華山の西端, 金華 山瀬戸に面して, 東西 $200 \mathrm{~m}$, 南北 $500 \mathrm{~m}$ の範囲で黒雲母 片岩, 黒雲母片麻岩, 角閃岩, 単斜輝石石英片岩, 石灰質 片岩, 花崗岩質片麻岩が見られる。超苦鉄質岩も露出する が, 変成岩類との関係は不明である(滝沢ら，1974)。蛇紋 岩化が進んでいるが，かんらん石，トレモライト，滑石を 含むこともある(猪木ら，1972)。また，猪木ら(1972)によ ると, 全岩組成は $\mathrm{Al}_{2} \mathrm{O}_{3}$ にそしく $(1.4 \%), \mathrm{CaO}$ をほとん ど含まず $(0.07 \%), \mathrm{MgO}$ に富久 $(48.2 \%, \mathrm{Mg} \# 0.930)$, ダ ナイト質である。超苦鉄質岩は西端の岬付近の転石をサン プリングした。

\section{6. 丸森}

宮城県南部の丸森町上滝の国民宿舎付近から堂平山の西 斜面一帯に, 東西 $400 \mathrm{~m}$, 南北 $4500 \mathrm{~m}$ の範囲で超苦鉄質 岩とそれに伴う泥質片岩, 珪質岩, 角閃岩が白亜紀花崗岩 中に分布している(藤田ら，1988）。超苦鉄質岩は輝石とか んらん石を含むことがある(青木 ・ 船山，1982）。堂平山北 西の清滝周辺の露頭からサンプリングした。

\section{7. 摺上}

福島県福島市北西の摺上地域は奥羽脊梁山脈南部に位置 し，ほとんぞ花崗岩によって占められるが，その捕獲岩と して数 $\mathrm{m} \sim$ 数 $100 \mathrm{~m}$ 大の黒雲母片岩, 角閃岩, 超苦鉄質 岩などが産し，西方の栗子山などにも同様の変成岩類が分 布する。超苦鉄質岩は蛇紋岩化し, 局所的にかんらん石が 見られる。変成鉱物 (トレモライト, 滑石など) の種類及び 岩石の組織から，原岩はダナイト〜ウェルライト質かんら 几岩と考えられていた(八島ら，1982)。今回は烏川の露頭 で超苦鉄質岩をサンプリングしたが，これは斜方輝石を含 むので, 原岩はハルツバージャイトだった可能性がある。

\section{III. 岩石記 載}

各地域においてサンプリングした岩石を顕微鏡観察し， 鉱物組み合わせ，組織を観察した。

\section{1. 和賀仙人}

超苦鉄質岩は黒色〜暗緑色, 塊状である。蛇紋石からな り, 滑石や緑泥石, 赤褐色スピネル残晶, 不透明鉱物が見 られる。蛇紋石は細粒であまり網目状組織を示さない。

\section{2. 焼石岳}

超苦鉄質岩は暗緑色〜黒色緻密で塊状又は片状である。 主に蛇紋石, ホルンブレンドないしトレモライトからな り, 滑石, 方解石, 赤褐色スピネル残晶, 不透明鉱物を含 む。蛇紋石は網目状組織を示し, 場合により緑泥石に变質 している。

\section{3. 母体}

超苦鉄質岩は暗緑色で片状である。蛇紋石からなり, 方 解石, 不透明鉱物を含む(Fig. 2a)。スピネルは不透明で ある。蛇紋石の網目状組織が発達している。

\section{4. 川渡}

超苦鉄質岩は完全に蛇紋岩化していて, 明緑色〜黒色を 呈し, 塊状である。蛇紋石からなり, 滑石, 緑泥石, 褐色 〜暗赤褐色スピネル残晶, 不透明鉱物を含む。蛇紋石は網 目状組織を示す。

\section{5. 金華山}

超苦鉄質岩は暗緑色〜褐色で塊状である。主にかんらん 石からなり, 角閃石, 褐色スピネル残晶, 蛇紋石, 滑石, 不透明鉱物を含む。かんらん石が細粒の部分と比較的粗粒 な部分があり, 後者では割れ目に沿って蛇紋石化, 細粒化 していることがある。細粒化している部分では, 複数の隣 り合う結晶の方位が揃っている(Fig. 2b)。 

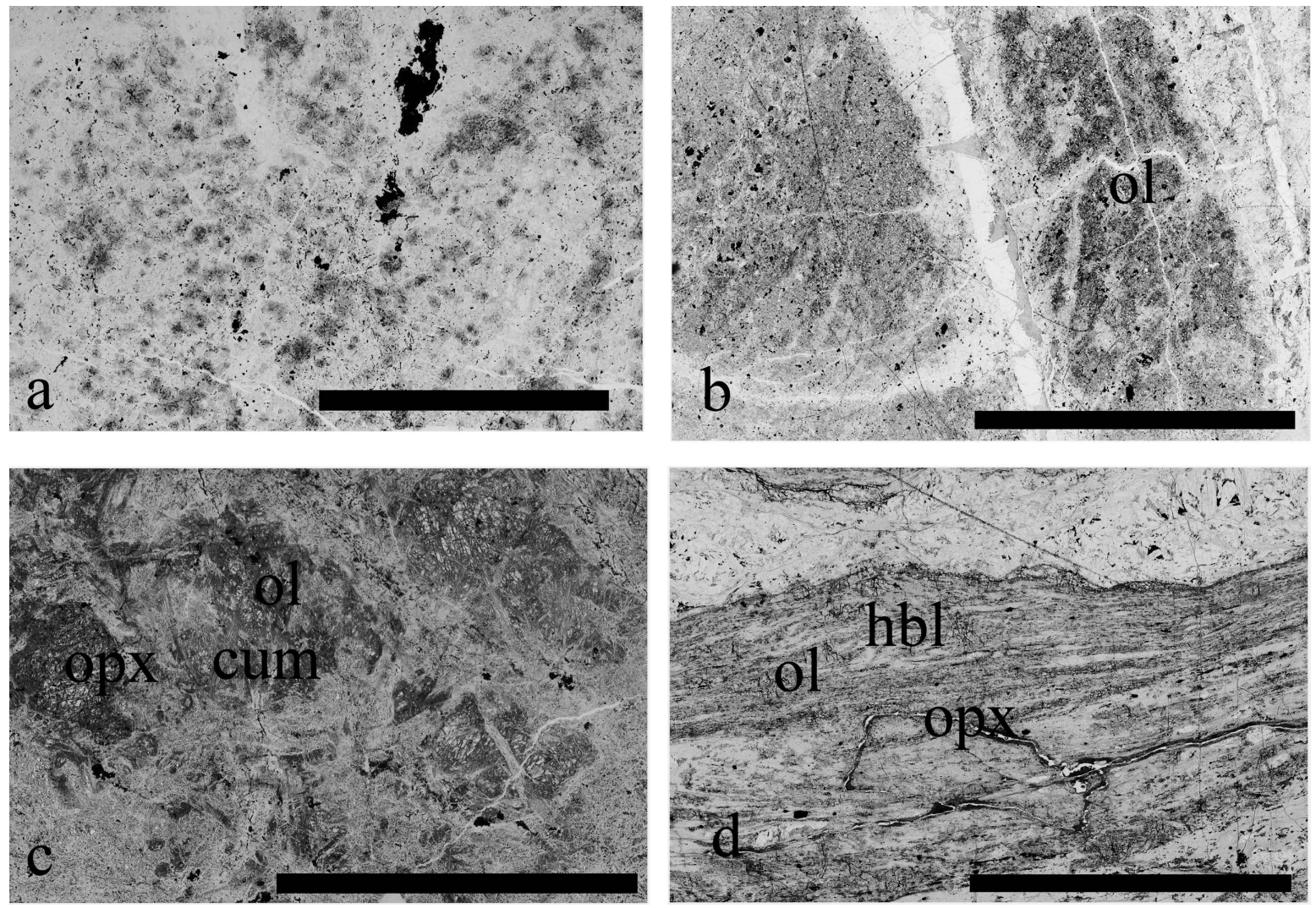

Fig. 2. Microscope images of thin sections of the ultramafic rocks. Open nicol. (a) Motai serpentinite (black altered spinels occur in the serpentine matrix), (b) Kinkasan serpentinite, (c) Marumori serpentinite, (d) Mamurori hornblendite,; ol, olivine; opx, orthopyroxene; cum, cummingtonite; hbl, hornblende. Each black bar represents $1 \mathrm{~cm}$.

\section{6. 丸森}

超苦鉄質岩は 2 種類見られた。堂平山西方のものは暗緑 色〜黒色で塊状である。主に蛇紋石からなり，斜方輝石， かんらん石，角閃石(カミングトン閃石)，褐色スピネル残 晶，不透明鉱物を含む。斜方輝石の割れ目に沿って蛇紋石 が形成されている(Fig. 2c)。かんらん石は蛇紋石によって 隔てられた粒子同士で結晶の方位が揃っていることがあ る。蛇紋石は網目状組織を示す。一方, 堂平山南西では片 状であり，ほとんど角閃石(ホルンブレンド)からなる角閃 石岩が産し，かんらん石，斜方輝石，褐色〜緑色スピネ ル，斜長石，不透明鉱物を含む(Fig. 2d)。滑石を含むこ ともある(藤田ら，1988)。角閃石はネマトブラスティック 組織を示す。かんらん石や斜方輝石は斑状変晶をなし，角 閃石を包有する。長石は緑色スピネルと伴う。

\section{7. 摺上}

超苦鉄質岩は暗緑色〜黒色塊状である。主に蛇紋石から なり, かんらん石, 角閃石(トレモライト), 褐色スピネル 残晶, 斜方輝石, 緑泥石, 不透明釷物を含む。蛇紋石に隔 てられた隣り合う複数の斜方輝石は結晶方位が一致するこ とが多いが，蛇紋石に隔てられたかんらん石の結晶方位が 一致することは希である。蛇紋石は網目状組織を示す。

\section{IV. 鉱物化学組成}

東北大学理学部地球惑星物質科学科のエネルギー分散型 EPMA (JEOL JSM-5410, Oxford Link ISIS)を用いて鉱物 化学組成を測定した。和賀仙人, 焼石岳, 母体, 川渡, 金 華山, 丸森, 摺上の 7 地域の超苦鉄質岩試料について測定 した。和賀仙人, 金華山の試料は転石であるが, 他は露頭 から採集した。スピネルのストイキオメトリーから $\mathrm{Fe}^{3+}$ を見積もった。

和賀仙人, 焼石岳, 川渡, 金華山, 摺上のスピネル粒子 には明瞭な累帯構造が見られ，均質で褐色透明なコアと， その周りの不透明なりムが不連続に接している( Fig. 3a)。母体, 丸森では均質なコアは見られず，コアからリ ムに向けて連続的に変化する(Fig. 3b)。透明部分は $\mathrm{Fe}^{3+}$ に乏しい $\mathrm{Cr}-\mathrm{Al}$ スピネル，不透明部分は $\mathrm{Fe}^{3+}$ に富む $\mathrm{Cr}$ スピネル，フェリットクロマイトないし磁鉄鉱である。和 賀仙人, 焼石岳, 川渡, 金華山, 母体ではリムに向けて $\mathrm{Fe}^{3+}$ が増加する傾向が見られたのに対し, 摺上, 丸森で は $\mathrm{Fe}^{3+}$ は増えずに $\mathrm{Cr} \#$ が変化した。以下では, 原岩の鉱 物化学組成を残している可能性が高いコアの $\mathrm{Cr}-\mathrm{Al}$ スピ ネルについて検討する。分析結果は Table 1 に示し，その 

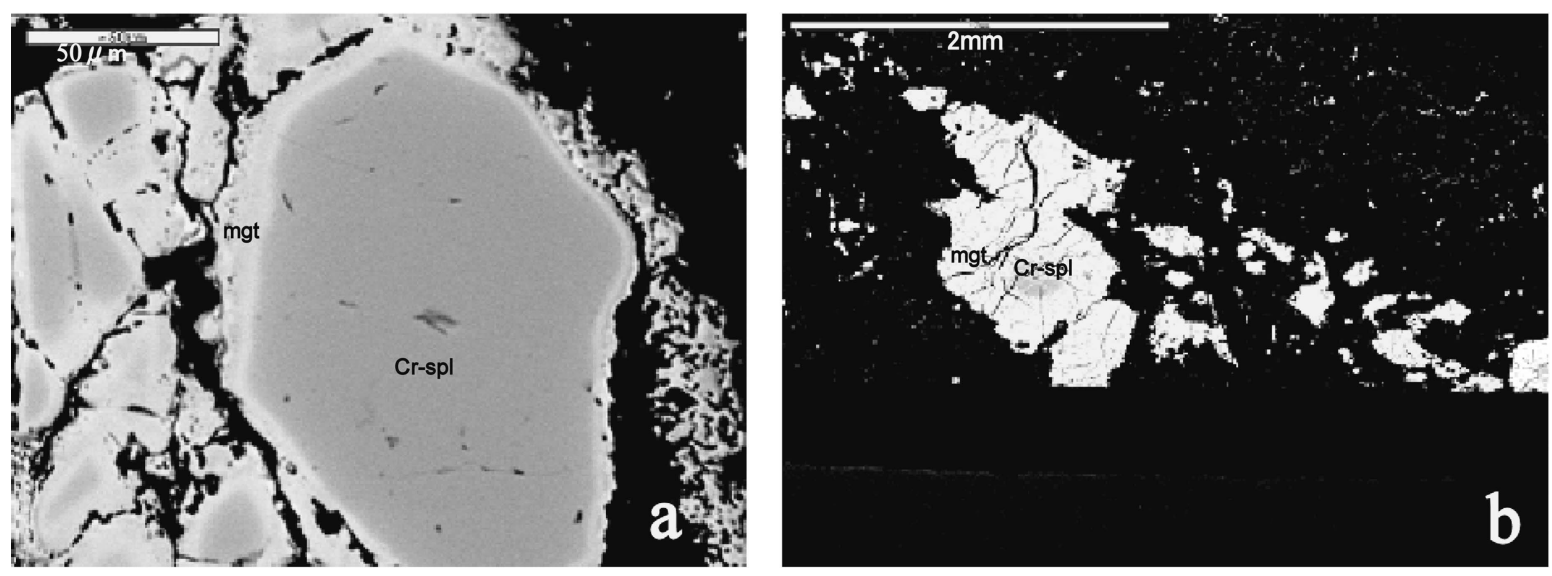

Fig. 3. Back-scattered electron images of spinels in the ultramafic rocks (a) Yakeishideka, (b) Motai. Cr-spl, Chromian spinel; mgt, magnetite.

概要を Table 2 にまとめ, Figures 4, 5, 6 に図示した。Cr\# $=\mathrm{Cr} /(\mathrm{Cr}+\mathrm{Al}), \mathrm{Mg} \#=\mathrm{Mg} /\left(\mathrm{Fe}^{2+}+\mathrm{Mg}\right)$ とする。

北部の和賀仙人，焼石岳，金華山，母体では $\mathrm{Cr}$ に富み ( $\mathrm{Mg} \#>0.2$ のものについて $\mathrm{Cr} \# 0.90-0.65)$ ，その原岩には $\mathrm{Cr} \#>0.80$ の高枯渴度かんらん岩が含まれる。同じ $\mathrm{Cr} \#$ の もので Mg\#を比べると，母体のものだけが他地域のもの より Mg\#に富むが (Fig. 5, Table 2), 同時にこれらは $\mathrm{Fe}^{3+}$ にも富んでおり(Fig. 4), コアからリムへ漸移的に化 学組成が変化しているので, 変質による組成変化の影響で あろう。宮守 . 早池峰両岩体から報告されている $\mathrm{Cr} \#<$ 0.40 のスピネルを含むかんらん岩 (ASPP; Ozawa, 1988) が全く産しないことが注目される。

南部の丸森, 摺上のスピネルは $\mathrm{Al}$ に富むが (蛇紋岩 かんらん岩で Cr\#0.65-0.30，角閃石岩で Cr\#0.65-0.01)， 唯一阿武郎帯の超苦鉄質岩体である摺上のものは $\mathrm{Cr} \# 0.64$ -0.61 であり，北上帯北部のものと大差はない。丸森・摺 上のスピネルは川渡を含む北部のものより $\mathrm{Fe}^{3+}$ に富んで いるが(Fig. 4), これらが花崗岩中の捕獲岩体として産す ることから, 再結晶作用の影響であろうと考えられる。

川渡のスピネルは Cr\#0.70-0.50であり，上の 2 つのグ ループの中間であるが， $\mathrm{Cr}$ \#50のものについて比べると， 丸森・摺上のものは $\mathrm{Mg}$ 0 0.50-0.55 程度であるのに対し, 川渡のものは Mg\#0.70 以上の高い值を示す (Fig. 5, Table 2)。川渡のスピネルは $\mathrm{Fe}^{3+}$ が非常に低いので (Fig. 4),

この高い $\mathrm{Mg}$ \# は変質による組成変化の影響ではなく, も とのかんらん岩の平衡温度が高かったことを示すと考えら れる。

なお， $\mathrm{TiO}_{2}$ 量はすべての地域で $1 \mathrm{wt} \%$ 以下の低い值を 示した $($ Fig. 6)。

かんらん石は丸森, 金華山, 摺上の超苦鉄質岩中と焼石 岳のスピネル中の包有物を測定した (Table 3)。丸森の蛇 紋岩で $\mathrm{Mg} \# 0.93-0.92$ ，角閃石岩では $\mathrm{Mg} \# 0.82-0.78$ であ る。金華山の超苦鉄質岩では $\mathrm{Mg} \# 0.87$, 習上では $\mathrm{Mg} \#$
0.91，焼石岳のスピネル中の包有物は $\mathrm{Mg} \# 0.92$ である。 超苦鉄質岩中で比べると，金華山が他よりもやや鉄に富む。

斜方輝石は丸森の蛇紋岩で $\mathrm{Mg} \# 0.92$, 摺上では $\mathrm{Mg}$ \# 0.90 であり, いずれも $\mathrm{Al}_{2} \mathrm{O}_{3}(<1.5 \mathrm{wt} \%), \mathrm{CaO}(<0.13$ wt \% ) に乏しく (Table 3), 変成斜方輝石である。

角閃石の化学組成について, $\mathrm{O}=23$ として, $\mathrm{Fe}^{3+}$ は分 析值をもとに全陽イオンを 46 としたときに， T 抢よび M1-M3 サイトの合計が 13 になるように計算し, T-M3 サ イトの合計が 13 を超えないものは, すべて $\mathrm{Fe}^{2+}$ とし た。ただし各サイトの求め方は Brown (1977)に従った。 角閃石は焼石岳, 丸森, 摺上で測定した (Table 4)。焼石 岳, 丸森の角閃石岩ではホルンブレンド組成, 丸森の蛇紋 岩ではカミングトナイト組成, 摺上ではトレモライト組成 である。

\section{V. 議論}

1. 宮守 · 早池峰超苦鉄質岩体との比較

金華山, 丸森では形態から初生的と考えられるかんらん 石が見られるが，他の超苦鉄質岩体は蛇紋岩化が進み，丸 森，金華山，摺上では一部の蛇紋岩に接触変成作用による 二次かんらん石や角閃石, 斜方輝石 (丸森の角閃岩にも見 られる)などを生じている。そのため，これらの岩体では 珪酸塩鉱物は初生的な情報をほとんど残していないと考え られる。スピネルについては, 和賀仙人, 焼石岳, 川渡, 金華山，母体のようなリムに向けての $\mathrm{Fe}^{3+}$ の増加は変成 作用の影響と考えられる(Barnes, 2000)。一方, 摺上, 丸 森のような $\mathrm{Fe}^{3+}$ 増加しない $\mathrm{Cr} \#$ の変化は, メルトとの 反応を示しているかもしれない(Barnes and Roeder, 2001)。しかしながら, 和賀仙人, 焼石岳, 川渡, 金華 山，摺上ではコアとリムに明瞭な組成差が現れ，コアで初 生的な組成を残していると考えられる。母体，丸森ではコ アとリムで組成が連続的に変化するが，コアの中心部分は 初生的な組成を残しているものとして扱う。 
Table 1. Chemical composition of spinels in the analyzed ultramafic rocks

\begin{tabular}{|c|c|c|c|c|c|c|c|c|c|}
\hline Type & Cr-rich & & & & & & & & \\
\hline Location & Wakasennin & & Yakeishidake & & & Motai & & & Kinkasan \\
\hline Sample 1 & $100906 \mathrm{P} 184$ & & 9090918 & & $11071610-2$ & 0909064A & & & $100425 f$ \\
\hline No. & $1102268 \mathrm{c}$ & $1102269 \mathrm{r}$ & $10062501 \mathrm{c}$ & $10062517 \mathrm{r}$ & $1109046 \mathrm{c}$ & $10072201 \mathrm{c}$ & $10072205 \mathrm{c}$ & $10072202 \mathrm{r}$ & - 11030311 \\
\hline $\mathrm{TiO}_{2}$ & 0.00 & 0.03 & 0.07 & 0.10 & 0.00 & 0.00 & 0.02 & 0.09 & 0.29 \\
\hline $\mathrm{Al}_{2} \mathrm{O}_{3}$ & 14.99 & 9.50 & 13.00 & 5.32 & 14.08 & 6.24 & 7.14 & 0.56 & 8.08 \\
\hline $\mathrm{Cr}_{2} \mathrm{O}_{3}$ & 50.98 & 46.62 & 52.31 & 40.97 & 48.63 & 50.54 & 52.07 & 19.73 & 54.31 \\
\hline $\mathrm{Fe}_{2} \mathrm{O}_{3}$ & 1.46 & 11.33 & 2.44 & 20.40 & 4.34 & 12.33 & 9.37 & 48.22 & 4.50 \\
\hline $\mathrm{FeO}$ & 21.97 & 24.97 & 20.68 & 25.22 & 17.69 & 21.97 & 21.71 & 29.31 & 26.60 \\
\hline $\mathrm{MnO}$ & 0.15 & 0.84 & 0.23 & 0.33 & 0.32 & 0.51 & 0.35 & 0.99 & 0.25 \\
\hline $\mathrm{MgO}$ & 7.33 & 4.52 & 7.96 & 3.79 & 9.45 & 6.29 & 6.54 & 0.37 & 3.95 \\
\hline $\mathrm{NiO}$ & 0.13 & 0.00 & 0.01 & 0.17 & 0.00 & 0.14 & 0.18 & 0.63 & 0.02 \\
\hline total & 97.01 & 97.81 & 96.70 & 96.30 & 94.51 & 98.03 & 97.38 & 99.90 & 98.00 \\
\hline $\mathrm{O}=$ & 4 & 4 & 4 & 4 & 4 & 4 & 4 & 4 & 4 \\
\hline $\mathrm{Ti}$ & 0.000 & 0.001 & 0.002 & 0.003 & 0.000 & 0.000 & 0.001 & 0.003 & 0.008 \\
\hline $\mathrm{Al}$ & 0.598 & 0.396 & 0.523 & 0.232 & 0.569 & 0.260 & 0.297 & 0.025 & 0.338 \\
\hline $\mathrm{Cr}$ & 1.365 & 1.302 & 1.411 & 1.196 & 1.319 & 1.412 & 1.453 & 0.592 & 1.526 \\
\hline $\mathrm{Fe}^{3+}$ & 0.037 & 0.301 & 0.063 & 0.567 & 0.112 & 0.328 & 0.249 & 1.378 & 0.120 \\
\hline $\mathrm{Fe}^{2+}$ & 0.622 & 0.738 & 0.590 & 0.779 & 0.508 & 0.649 & 0.641 & 0.931 & 0.790 \\
\hline $\mathrm{Mn}$ & 0.004 & 0.025 & 0.007 & 0.010 & 0.009 & 0.015 & 0.010 & 0.032 & 0.008 \\
\hline $\mathrm{Mg}$ & 0.370 & 0.238 & 0.405 & 0.209 & 0.483 & 0.331 & 0.344 & 0.021 & 0.209 \\
\hline $\mathrm{Ni}$ & 0.004 & 0.000 & 0.000 & 0.005 & 0.000 & 0.004 & 0.005 & 0.019 & 0.001 \\
\hline total & 3.000 & 3.000 & 3.000 & 3.000 & 3.000 & 3.000 & 3.000 & 3.000 & 3.000 \\
\hline $\mathrm{Cr} \#$ & 0.70 & 0.77 & 0.73 & 0.84 & 0.70 & 0.84 & 0.83 & 0.96 & 0.82 \\
\hline $\mathrm{Y}_{\mathrm{Cr}}$ & 0.68 & 0.65 & 0.71 & 0.60 & 0.66 & 0.71 & 0.73 & 0.30 & 0.77 \\
\hline $\mathrm{Y}_{\mathrm{Fe}}{ }^{3+}$ & 0.02 & 0.15 & 0.03 & 0.28 & 0.06 & 0.16 & 0.12 & 0.69 & 0.06 \\
\hline Mg\# & 0.37 & 0.24 & 0.41 & 0.21 & 0.49 & 0.34 & 0.35 & 0.02 & 0.21 \\
\hline Type & Al-rich & & & & & & & Mg-rich & \\
\hline Location & Marumori & & & & & Surikami & & Kawatabi & \\
\hline Sample & 10050502 & & 11072306 (ho & ornblendite) & & 10111305 & & 90609 & \\
\hline No. & 1011267 & $1021510 \mathrm{c}$ & 11102612 & $11102614 \mathrm{c}$ & $11102615 \mathrm{r}$ & $11082502 \mathrm{r}$ & $11082505 \mathrm{c}$ & $10062510 \mathrm{c}$ & $10062513 \mathrm{r}$ \\
\hline $\mathrm{TiO}_{2}$ & 0.28 & 0.05 & 0.00 & 0.57 & 0.03 & 0.17 & 0.24 & 0.01 & 0.09 \\
\hline $\mathrm{Al}_{2} \mathrm{O}_{3}$ & 23.53 & 28.86 & 53.97 & 16.48 & 46.64 & 25.57 & 17.09 & 26.92 & 0.11 \\
\hline $\mathrm{Cr}_{2} \mathrm{O}_{3}$ & 30.96 & 26.50 & 7.13 & 44.57 & 14.76 & 34.04 & 42.06 & 40.88 & 1.31 \\
\hline $\mathrm{Fe}_{2} \mathrm{O}_{3}$ & 13.17 & 11.08 & 3.36 & 3.36 & 2.93 & 9.51 & 9.52 & 2.87 & 66.60 \\
\hline $\mathrm{FeO}$ & 17.04 & 16.14 & 14.39 & 26.15 & 17.07 & 19.71 & 21.80 & 11.35 & 29.84 \\
\hline $\mathrm{MnO}$ & 0.20 & 0.20 & 0.04 & 0.42 & 0.04 & 0.22 & 0.06 & 0.22 & 0.00 \\
\hline $\mathrm{MgO}$ & 11.24 & 12.04 & 15.92 & 4.85 & 13.53 & 10.45 & 8.19 & 15.68 & 0.18 \\
\hline $\mathrm{NiO}$ & 0.38 & 0.14 & 0.12 & 0.00 & 0.00 & 0.14 & 0.19 & 0.09 & 0.68 \\
\hline total & 96.80 & 95.02 & 94.93 & 96.39 & 95.00 & 99.81 & 99.15 & 98.02 & 98.81 \\
\hline $\mathrm{O}=$ & 4 & 4 & 4 & 4 & 4 & 4 & 4 & 4 & 4 \\
\hline $\mathrm{Ti}$ & 0.007 & 0.001 & 0.000 & 0.015 & 0.001 & 0.004 & 0.006 & 0.000 & 0.003 \\
\hline $\mathrm{Al}$ & 0.887 & 1.073 & 1.772 & 0.669 & 1.596 & 0.935 & 0.661 & 0.958 & 0.005 \\
\hline $\mathrm{Cr}$ & 0.783 & 0.661 & 0.157 & 1.214 & 0.339 & 0.835 & 1.092 & 0.976 & 0.040 \\
\hline $\mathrm{Fe}^{3+}$ & 0.317 & 0.263 & 0.071 & 0.087 & 0.064 & 0.222 & 0.235 & 0.065 & 1.949 \\
\hline $\mathrm{Fe}^{2+}$ & 0.456 & 0.426 & 0.335 & 0.753 & 0.414 & 0.511 & 0.598 & 0.287 & 0.971 \\
\hline $\mathrm{Mn}$ & 0.005 & 0.005 & 0.001 & 0.012 & 0.001 & 0.006 & 0.002 & 0.006 & 0.000 \\
\hline $\mathrm{Mg}$ & 0.536 & 0.566 & 0.661 & 0.249 & 0.585 & 0.483 & 0.401 & 0.706 & 0.010 \\
\hline $\mathrm{Ni}$ & 0.010 & 0.004 & 0.003 & 0.000 & 0.000 & 0.003 & 0.005 & 0.002 & 0.021 \\
\hline total & 3.000 & 3.000 & 3.000 & 3.000 & 3.000 & 3.000 & 3.000 & 3.000 & 3.000 \\
\hline $\mathrm{Cr} \#$ & 0.47 & 0.38 & 0.08 & 0.64 & 0.18 & 0.47 & 0.62 & 0.50 & 0.89 \\
\hline $\mathrm{Y}_{\mathrm{Cr}}$ & 0.39 & 0.33 & 0.08 & 0.62 & 0.17 & 0.42 & 0.55 & 0.49 & 0.02 \\
\hline $\mathrm{Y}_{\mathrm{Fe}}{ }^{3+}$ & 0.16 & 0.13 & 0.04 & 0.04 & 0.03 & 0.11 & 0.12 & 0.03 & 0.98 \\
\hline $\mathrm{Mg \#}$ & 0.54 & 0.57 & 0.66 & 0.25 & 0.59 & 0.49 & 0.40 & 0.71 & 0.01 \\
\hline
\end{tabular}


Table 2. Summary of spinel chemistry in the analyzed ultramafic rocks

\begin{tabular}{lllll}
\hline Type & Location & $\mathrm{Cr} \#$ & $\mathrm{Mg} \#($ at Cr\#50) & $\mathrm{TiO}_{2}(\mathrm{wt} \%)$ \\
\hline Cr-rich & Wakasennin & $0.77-0.70$ & $0.37-0.24(0.50)$ & $0.00-0.13$ \\
& Yakeishidake & $0.85-0.64$ & $0.40-0.19(0.54)$ & $0.00-0.28$ \\
& Motai & $0.97-0.83$ & $0.33-0.09(0.60)$ & $0.00-0.51$ \\
& Kinkasan & $0.86-0.75$ & $0.28-0.21(0.51)$ & $0.29-0.90$ \\
\hline Al-rich & & & & \\
& Marumori (serpentinite) & $0.53-0.35$ & $0.67-0.48(0.53)$ & $0.05-0.28$ \\
& Marumori (hornblendite) & $0.64-0.08$ & $0.72-0.25$ & $0.00-0.57$ \\
& Surikami & $0.64-0.24$ & $0.41-0.39(0.50)$ & $0.17-0.32$ \\
\hline Mg-rich & & & & \\
& Kawatabi & $0.73-0.50$ & $0.72-0.44(0.71)$ & $0.00-0.07$ \\
\hline
\end{tabular}

$\mathrm{Mg} \#$ at $\mathrm{Cr} \# 50$ is estimated following the general chemical trends.

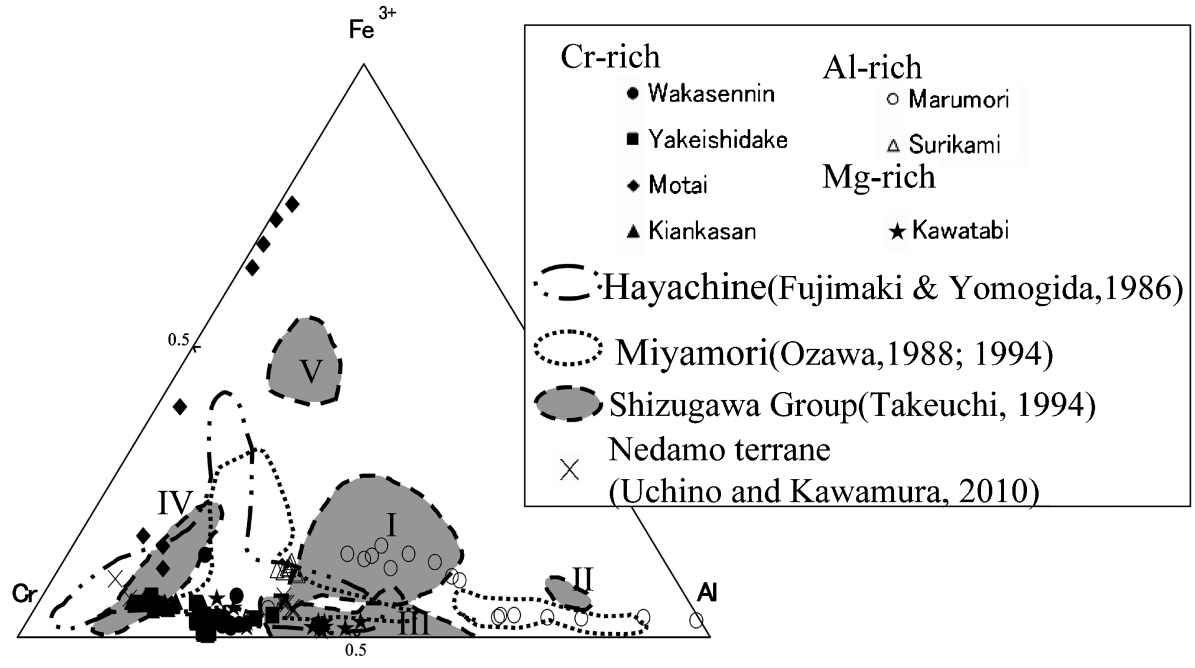

Fig. 4. $\mathrm{Fe}^{3+}-\mathrm{Cr}-\mathrm{Al}$ ternary diagram for analyzed spinels. Dashed line encircles the compositional field of spinels from the Hayachine ultramafic body (after Fujimaki and Yomogida, 1986a, 1986b). Dotted line encloses the compositional field of spinels from the Miyamori ultramafic body (after Ozawa, 1988, 1994).
東北地方で超苦鉄質岩が最も大規模に分布するのは，北 上山地の早池峰及び宮守の両岩体であるが，宮守岩体と早 池峰岩体の間にスピネルの組成差があるかどうかははっき りしない。Fujimaki and Yomogida (1986a, 1986b)による 早池峰のスピネルの分析データとOzawa (1988，1994)の 宮守のデータを比べると, 早池峰の方が $\mathrm{Cr}$ \#が高いよう に見えるが (Fig. 4), 最も Cr\#代低い $(0.12)$ マントル . レールゾライトは早池峰のサンプルであり，そのような レールゾライトは宮守より早池峰に多い。両岩体ともに非 常に広い組成範囲を示し，特にどちらが枯渴している $(\mathrm{Cr} \#$ が高い)とは断定できない(Ozawa，1988)。

本研究で測定した小規模超苦鉄質岩体のスピネル組成 は，地理的に東北地方の北部と南部で顕著な組成差を示 す。すなわち北部の和賀仙人，焼石岳，母体，金華山の蛇 紋岩中のものは $\mathrm{Cr}$ に富み $(\mathrm{Mg} \#>0.2$ のものについて $\mathrm{Cr} \#$ 0.65-0.90), 丸森と摺上の蛇紋岩中のものは $\mathrm{Al}$ に富む $(\mathrm{Cr} \#$ 0.30-0.65)。これらは早池峰・宮守両岩体のマントルかん らん岩及び超苦鉄質集積岩のスピネルの組成範囲に含まれ るが, $\mathrm{Al}$ に富む溶け残りマントルかんらん岩 (Ozawa,
1988 の ASPP)が北部の小岩体群に全く産しないことは特 筆される。丸森の $\mathrm{Al}$ に富むスピネルもその形態などから ASPPの溶け残りかんらん岩ではなく超苦鉄質集積岩が原 岩と考えられる。

一般に, $\mathrm{TiO}_{2}$ に富む砕屑性クロムスピネル粒子(志津川 層群のグループ I と V (竹内, 1992) や関東山地の山中地溝

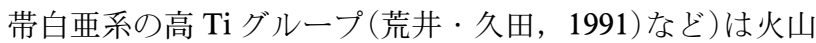
岩起源とされる。しかし, 宮守岩体のダナイトやウェルラ イトなどの超苦鉄質集積岩にも $\mathrm{TiO}_{2}$ に富むクロムスピネ ルを産するものがある(Ozawa, 1994) (Fig. 6)。本研究で 分析した東北地方の小規模蛇紋岩体のスピネルは，超苦鉄 質集積岩起源と考えられるものを含めて，ほとんど全て低 $\mathrm{Ti}$ 領域にプロットされ, 宮守岩体のような高 $\mathrm{Ti}$ スピネル は発見できなかった。

\section{2. 付加体 ·陸棚堆積物中の砕屑性スピネルとの比較}

石炭紀付加体である根田茂帯の礫岩中にみられる超苦鉄 質岩中のスピネルは早池峰, 宮守両岩体中のスピネルに類 似し(Uchino and Kawamura, 2010), 同じ Cr\#に対して $\mathrm{Mg} \#$ の異なる2つの傾向が見られる。このことから，和 


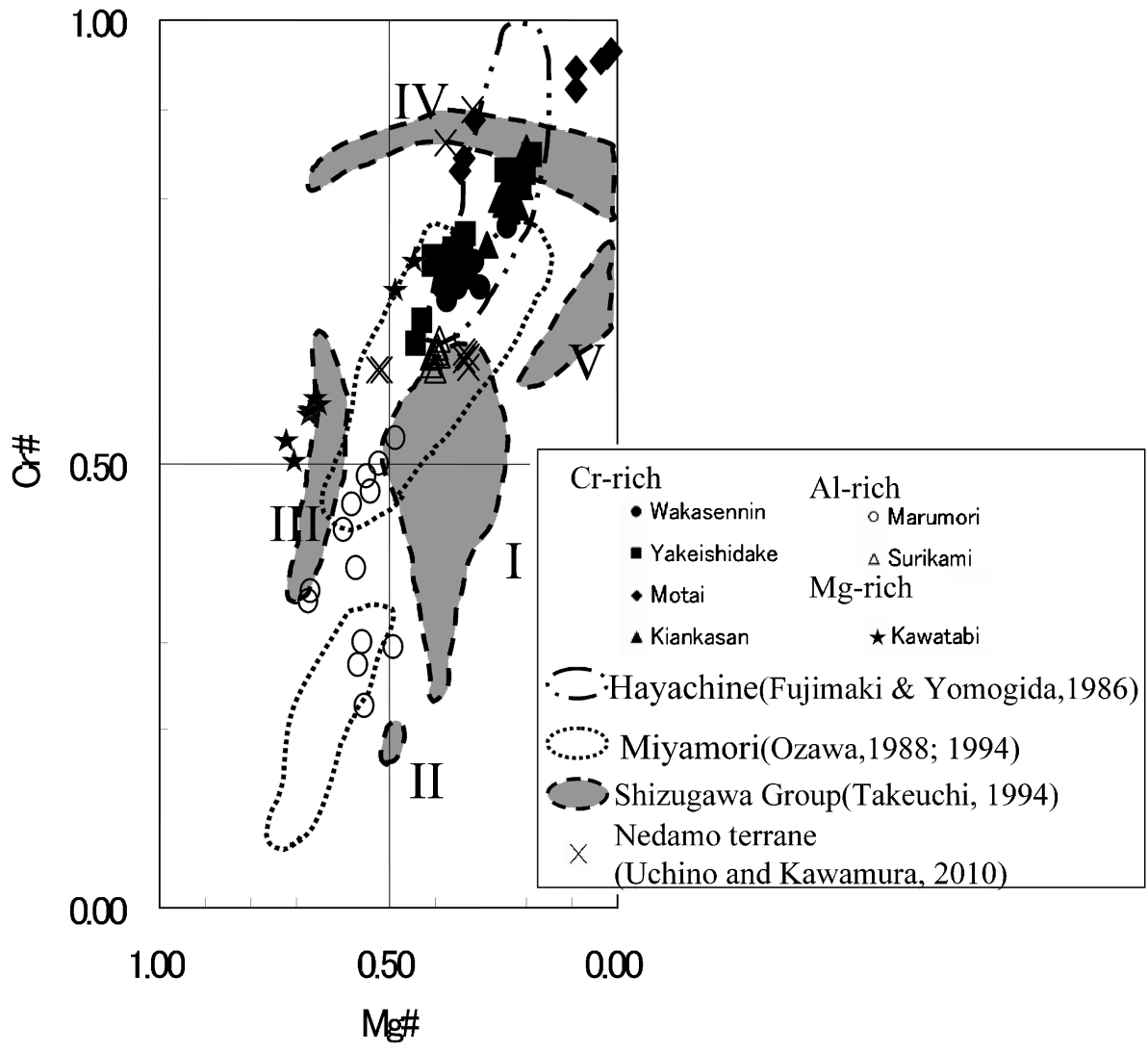

Fig. 5. Relationship between $\mathrm{Mg \#}$ and $\mathrm{Cr} \#$ among analyzed spinels. The areas numbered I-V are compositional fields of detrital chromian spinels from the Jurassic Shizugawa Group (Takeuchi1994).

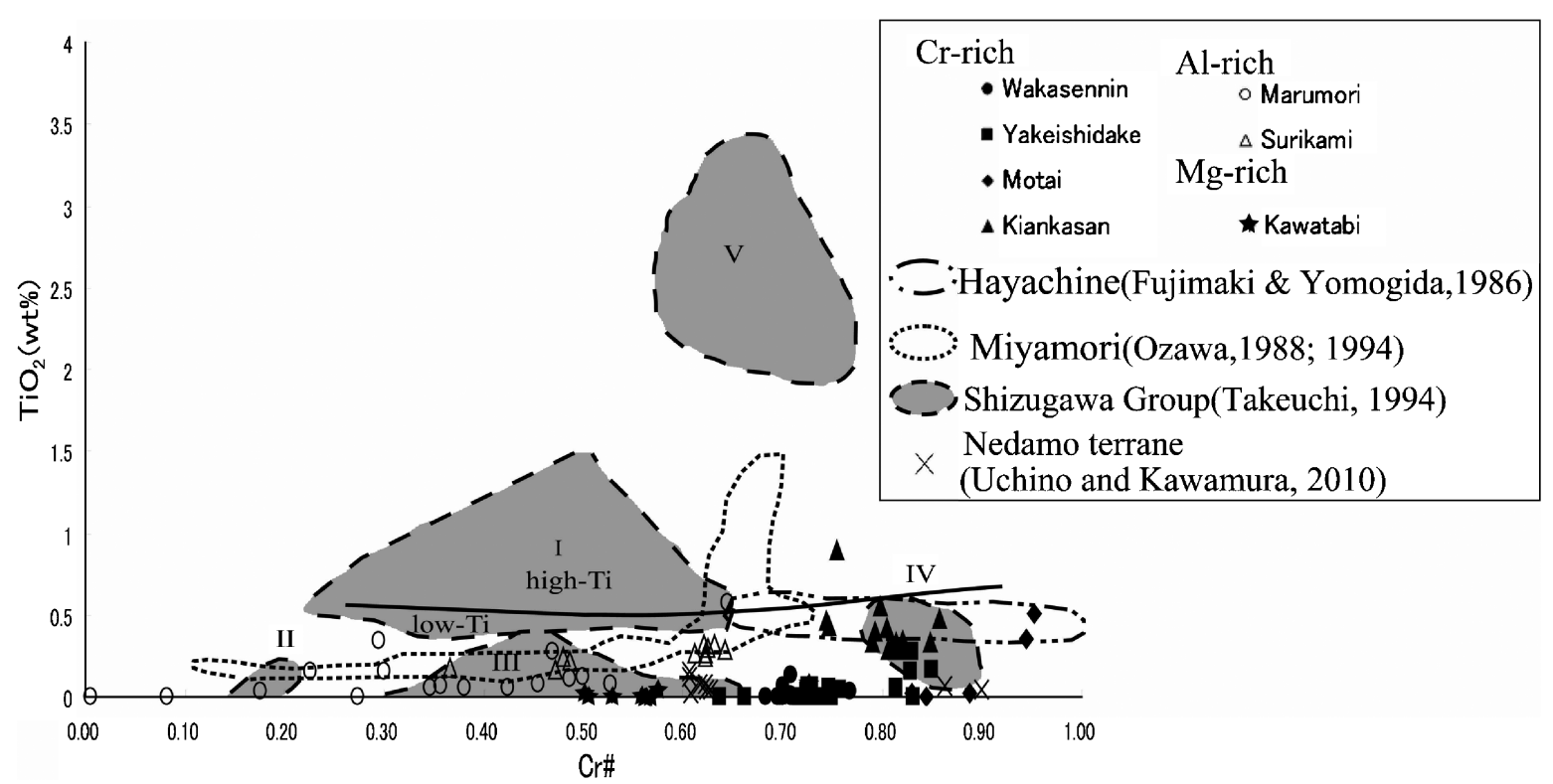

Fig. 6. Relationship between $\mathrm{Cr} \#$ and $\mathrm{TiO}_{2}$ among analyzed spinels. The location of boundary between the high- and low-Ti groups are after Arai and Hisada (1991). See Figures 2 and 3 for references of the marked fields. 
Table 3. Chemical composition of olivines and orthpyroxene in the analyzed ultramafic rocks

\begin{tabular}{|c|c|c|c|c|c|c|c|c|c|c|}
\hline Location & Yakeishidake & Keinkasan & & Marumori & & & & Surikami & & \\
\hline Sample & 9090918 & $100425 f$ & & 10050502 & & & 10072306 & 10111305 & & \\
\hline Mineral & $\mathrm{Ol}$ & $\mathrm{Ol}$ & $\mathrm{Ol}$ & $\mathrm{Ol}$ & $\mathrm{Ol}$ & Opx & $\mathrm{Ol}$ & $\mathrm{Ol}$ & $\mathrm{Ol}$ & Opx \\
\hline No. & 10062518 & 11030312 & 11030313 & 1011269 & 1102151 & 1102157 & 11102613 & 11082504 & 11082514 & 11082515 \\
\hline $\mathrm{SiO}_{2}$ & 41.11 & 40.96 & 40.74 & 41.47 & 41.03 & 56.55 & 39.70 & 41.68 & 41.97 & 58.12 \\
\hline $\mathrm{TiO}_{2}$ & & & & & & & & & & 0.08 \\
\hline $\mathrm{Al}_{2} \mathrm{O}_{3}$ & & & & & & 0.64 & & 0.03 & & 1.52 \\
\hline $\mathrm{Cr}_{2} \mathrm{O}_{3}$ & & & & & & 0.07 & & & & 0.20 \\
\hline $\mathrm{FeO}$ & 8.17 & 12.52 & 12.03 & 7.38 & 6.66 & 5.31 & 16.66 & 8.96 & 8.97 & 6.72 \\
\hline $\mathrm{MnO}$ & 0.16 & 0.18 & 0.25 & 0.04 & 0.14 & 0.11 & 0.21 & 0.17 & 0.11 & 0.04 \\
\hline $\mathrm{MgO}$ & 49.83 & 47.07 & 47.07 & 50.40 & 50.31 & 34.87 & 43.63 & 51.00 & 51.30 & 35.82 \\
\hline $\mathrm{CaO}$ & 0.01 & 0.02 & 0.00 & 0.00 & 0.00 & 0.07 & 0.05 & 0.00 & 0.02 & 0.13 \\
\hline $\mathrm{NiO}$ & 0.44 & 0.00 & 0.11 & 0.43 & 0.61 & & 0.04 & 0.39 & 0.37 & \\
\hline total & 99.72 & 100.75 & 100.20 & 99.72 & 98.75 & 97.62 & 100.29 & 102.23 & 102.74 & 102.63 \\
\hline$\overline{\mathrm{O}=}$ & 4 & 4 & 4 & 4 & 4 & 6 & 4 & 4 & 4 & $\overline{6}$ \\
\hline $\mathrm{Si}$ & 1.004 & 1.007 & 1.007 & 1.008 & 1.010 & 1.986 & 1.001 & 0.996 & 0.997 & 1.954 \\
\hline $\mathrm{Ti}$ & & & & & & & & & & 0.002 \\
\hline $\mathrm{Al}$ & & & & & & 0.026 & & 0.001 & & 0.060 \\
\hline $\mathrm{Cr}$ & & & & & & 0.002 & & & & 0.005 \\
\hline $\mathrm{Fe}$ & 0.167 & 0.257 & 0.249 & 0.150 & 0.137 & 0.156 & 0.351 & 0.179 & 0.178 & 0.189 \\
\hline $\mathrm{Mn}$ & 0.003 & 0.004 & 0.005 & 0.001 & 0.003 & 0.003 & 0.004 & 0.003 & 0.002 & 0.001 \\
\hline $\mathrm{Mg}$ & 1.814 & 1.725 & 1.733 & 1.826 & 1.845 & 1.825 & 1.640 & 1.816 & 1.817 & 1.795 \\
\hline $\mathrm{Ca}$ & 0.000 & 0.002 & 0.000 & 0.000 & 0.000 & 0.002 & 0.001 & 0.000 & 0.000 & 0.005 \\
\hline $\mathrm{Ni}$ & 0.009 & 0.000 & 0.002 & 0.008 & 0.012 & & 0.001 & 0.008 & 0.007 & \\
\hline total & 2.997 & 2.995 & 2.996 & 2.993 & 3.007 & 4.000 & 2.998 & 3.003 & 3.001 & 4.011 \\
\hline $\mathrm{Mg \#}$ & 0.92 & 0.87 & 0.87 & 0.92 & 0.93 & 0.92 & 0.82 & 0.91 & 0.91 & 0.90 \\
\hline
\end{tabular}

賀仙人，焼石岳，母体，金華山，川渡の超苦鉄質岩は石炭 紀には浸食され始めていたと考えられる。南部北上帯下部 ジュラ系志津川層群中の砂岩にふくまれる碎屑性スピネル は I〜Vのグループに分けられ，I， I は宮守オフィオラ イトに由来し, 残りは起源不明とされていた（竹内, 1994)。本研究のスピネルと比較すると, 和賀仙人, 焼石 岳，母体，金華山はグループ I と N の中間的な組成を示 す。川渡は $\mathrm{Cr}$ \#に対して $\mathrm{Mg} \#$ が高くグループIIIに類似す る。丸森，摺上はグループ I ， II 類似した組成を示す。 従って, 本研究の超苦鉄質岩はシュラ紀前期に扔いても砕 屑性スピネルを供給していたと考えられ，現在小規模岩体 であるこれらの岩体は，もともと大規模に露出していたも のが，その後の浸食削剥や構造運動によって小さくなった と考えられる。

\section{3. 北上帯と阿武隈帯の超苦鉄質岩について}

阿武隈帯に産する摺上の超苦鉄質岩体のスピネル組成は, Cr\#0.61-0.65であり, 北上帯北部の小岩体のものよりや や Cr\#落低いが, 大差はない。北上帯と阿武隈帯では, 超苦鉄質岩の組成に大きな差はない可能性がある。加納ら (1973)の竹貫図幅によると, 阿武隈帯の御斎所変成岩中の 超苦鉄質岩には辟開の発達したかんらん石が産するとのこ とで, 彼らは飛騨外縁帯や舞鶴帯の北側の超苦鉄質岩体 (現在の用語では大江山オフィオライト) との関連を示唆し ているが，このようなかんらん石 (cleavable olivine) は宮
守岩体にも広く産する(小澤一仁，私信）。本研究試料では 蛇紋岩化がかなり進行しているため, cleavable olivineは 確認できなかった。阿武隈帯は化石やジルコンの放射年代 の証拠からジュラ紀付加体を原岩とした白亜紀変成帯であ ると考元られ(Hiroi et al., 1987, 1998)，その付加体が形成 された前弧域にも北上帯のものとよく似た前弧オフィオラ イトが存在していたことになる。ただし，小論では阿武隈 帯の超苦鉄質岩についての広域的データが不足しており， 今後の研究課題である。

\section{4. 構造環境判別図における位置づけ}

超苦鉄質岩中のスピネルの化学組成を用いて超苦鉄質岩 の形成条件やテクトニックセッティングの推定を行う。ス ピネルの Mg\#は，共存するかんらん石の $\mathrm{Mg} \#$ が同じなら ば温度に依存して变化し(例えば, Fabriès, 1979), 溶け残 りかんらん岩の Cr\#\#、ントルの溶融程度 (枯渴度)を示 し，マントルかんらん岩よりも集積岩でスピネルの $\mathrm{TiO}_{2}$ 量が多くなる(Arai et. al., 2011)。中央海嶺では Cr\# が 0.6 以下で $\mathrm{TiO}_{2}$ 量に乏しい。ホットスポットでは $\mathrm{Cr} \#$ が 0.70.8 以下で $\mathrm{TiO}_{2}$ 量に富む。島弧では $\mathrm{Cr} \#$ が 0.9 以下で $\mathrm{TiO}_{2}$ 量は乏しいが中央海嶺よりは富む。今回分析した久 ピネルのコアの組成をこれら比較すると, 和賀仙人, 焼石 岳, 母体, 川渡, 金華山では $\mathrm{Cr} \#$ が高く $\mathrm{TiO}_{2}$ 量が低いこ とから島弧で形成されたマントルかんらん岩由来であると 考えられる。丸森と摺上では $\mathrm{Cr} \#$ が 0.6 程度ないしそれ以 
Table 4. Chemical composition of amphiboles in analyzed ultramafic rocks

\begin{tabular}{|c|c|c|c|c|}
\hline Location & Yakeishidake & Marumori & & Surikami \\
\hline Sample & 9090912 & 10050502 & 11072306 & 10111305 \\
\hline No. & $10072209 \mathrm{c}$ & 10112608 & 11102611 & 11083007 \\
\hline $\mathrm{SiO} 2$ & 44.52 & 58.58 & 51.00 & 55.22 \\
\hline $\mathrm{TiO}_{2}$ & 0.44 & 0.03 & 0.71 & 0.27 \\
\hline $\mathrm{Al}_{2} \mathrm{O}_{3}$ & 12.48 & 0.96 & 7.56 & 3.32 \\
\hline $\mathrm{Cr}_{2} \mathrm{O}_{3}$ & 1.07 & 0.11 & 0.19 & 0.30 \\
\hline $\mathrm{Fe}_{2} \mathrm{O}_{3}$ & 4.60 & 0.00 & 4.73 & 2.78 \\
\hline $\mathrm{FeO}$ & 3.11 & 5.52 & 0.00 & 0.00 \\
\hline $\mathrm{MnO}$ & 0.08 & 0.14 & 0.08 & 0.02 \\
\hline $\mathrm{MgO}$ & 16.54 & 30.47 & 19.52 & 22.65 \\
\hline $\mathrm{CaO}$ & 11.90 & 0.34 & 12.22 & 12.61 \\
\hline $\mathrm{Na}_{2} \mathrm{O}$ & 3.01 & 0.02 & 0.29 & 0.00 \\
\hline $\mathrm{K}_{2} \mathrm{O}$ & 0.19 & 0.07 & 0.08 & 0.10 \\
\hline total & 97.94 & 96.24 & 96.38 & 97.27 \\
\hline $\mathrm{O}=$ & 23 & 23 & 23 & 23 \\
\hline $\mathrm{Si}$ & 6.346 & 7.963 & 7.105 & 7.522 \\
\hline $\mathrm{Ti}$ & 0.047 & 0.003 & 0.074 & 0.028 \\
\hline AlIV & 1.654 & 0.037 & 0.895 & 0.478 \\
\hline AlVI & 0.442 & 0.118 & 0.347 & 0.054 \\
\hline $\mathrm{Cr}$ & 0.121 & 0.012 & 0.021 & 0.032 \\
\hline $\mathrm{Fe}^{3+}$ & 0.494 & 0.000 & 0.503 & 0.289 \\
\hline $\mathrm{Fe}^{2+}$ & 0.371 & 0.744 & 0.000 & 0.000 \\
\hline $\mathrm{Mn}$ & 0.010 & 0.016 & 0.010 & 0.002 \\
\hline $\mathrm{Mg}$ & 3.515 & 6.174 & 4.053 & 4.599 \\
\hline $\mathrm{Ca}$ & 1.837 & 0.050 & 1.849 & 1.870 \\
\hline $\mathrm{Na}_{\mathrm{M} 4}$ & 0.842 & 0.005 & 0.079 & 0.000 \\
\hline $\mathrm{Na}_{\mathrm{A}}$ & 0.000 & 0.000 & 0.000 & 0.000 \\
\hline K & 0.036 & 0.013 & 0.015 & 0.017 \\
\hline total & 15.715 & 15.135 & 14.950 & 14.892 \\
\hline $\mathrm{Mg} \#\left(\mathrm{Fe}^{2+}\right)$ & 0.90 & 0.89 & 1.00 & 1.00 \\
\hline $\mathrm{Mg} \#(\Sigma \mathrm{Fe})$ & 0.80 & 0.89 & 0.89 & 0.94 \\
\hline
\end{tabular}

下で $\mathrm{TiO}_{2}$ 量が低いことから島弧または中央海嶺で形成さ れた可能性がある。一方，例えば夜久野オフィオライトの グラニュライト相の変成集積岩のスピネルもこのような $\mathrm{Cr} \#$ の広い変化範囲と低い $\mathrm{TiO}_{2}$ 量を示すので(Ishiwatari, 1985a，1985b)，これと同様に緑海で形成された厚い海洋 地殼下のマントルを起源とする可能性もある。しかし，こ こでは地理的にも近く, 同様に $\mathrm{Al}$ に富み $\mathrm{Ti}$ に乏しい ASPP 系列のかんらん岩を産する, 島弧環境下で形成され た早池峰・宮守両岩体 (Ozawa，1988) に対比するのが最も 妥当であろう。

\section{5. 川渡の Mgに富むスピネルを含む蛇紋岩の起源}

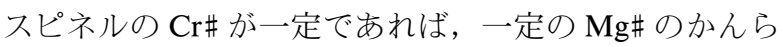
ん石と共存するスピネルの Mg\# は, 高温であるほど高く なり, $\mathrm{Fe}^{3+}$ が多いほど低くなる(e.g., Fabries, 1979)。川 渡地域の超苦鉄質岩中の $\mathrm{Mg}$ の の高いスピネルは, 川渡地 域の超苦鉄質岩が高温であった可能性を示唆する。そのよ
うな高温の超苦鉄質岩が露出する地域として, 伊豆マリア ナ弧や中央海嶺がある。川渡地域の超苦鉄質岩中のスピネ ルは組成から島弧で形成されたと考えられるので, 中央海 嶺起源は考えにくい。伊豆マリアナ弧の前弧域( Ohara and Ishii, 1998 の無水 $(\mathrm{A})$ タイプ)や母島海山 (Okamura et.

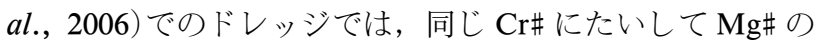
高いスピネルが発見されている。川渡地域の超苦鉄質岩も このように角閃石などの含水鉱物を含まない前弧域の無水 かんらん岩であった可能性がある。これは, 根田茂帯中の 超苦鉄質岩の砝屑物が前弧域から供給されたというUchino and Kawamura(2010)の結論にも調和的である。

\section{VI. 結 論}

本研究では, 東北地方の小規模超苦鉄質岩体について, 北から南へ和賀仙人, 焼石岳, 母体, 川渡, 金華山, 丸 森, 摺上で試料を採取し, 顕微鏡観察とスピネル・かんら ん石の EPMA 分析を行った。摺上は阿武隈帯に属するが 他は北上帯に属する。和賀仙人, 焼石岳, 母体, 金華山, 摺上の超苦鉄質岩は早池峰・宮守両岩体の $\mathrm{Cr}$ に富むスピ ネルを含むマントルかんらん岩・輝石岩 (CSPP) に一致す るスピネル組成を示す。ただし，金華山のかんらん石はや や鉄に富む $\left(\mathrm{Fo}_{87}\right)$ 。丸森のものは $\mathrm{Al}$ に富むスピネルを含 み, 宮守・早池峰の ASPP に類似する。川渡の蛇紋岩中 のスピネルは $\mathrm{Cr}$ 量がこれらの中間であるが，非常に $\mathrm{Mg}$ に富む特徵があり, 前弧域の無水かんらん岩に類似する。 このタイプのスピネルは, 宮守. 早池峰には産しないが, ジュラ系志津川層群の砕屑粒子として報告されて抢り, 川 渡の蛇紋岩はその供給源の一つであることがわかった。 従って, これらの超苦鉄質岩体は, もともと宮守·早池峰 超苦鉄質複合岩体と一連の岩体として, 古生代後期 中生 代にわたり, 北上帯と阿武隈帯の付加体や陸棚堆積物が形 成された前弧の陸域に広く露出していたと考えられる。

謝 辞 本稿は第一著者の東北大学理学研究科地学専攻 の修士論文の一部をもとにまとめたものである。第一著者 は在学中にお世話になったすべての同専攻の教員・学生の 方々に心より感謝する。母体のサンプルは吉田武義先生の 巡検に参加して採集した。この研究の費用の一部として第 二著者への科学研究費補助金基盤研究 (C) 23540554 を使用 した。JAMSTEC 阿部なつ江氏, 千葉大学廣井美邦氏の 両氏には査読を通して有益な助言をいただいた。この場を 借りてお礼申し上げます。

\section{引用文献}

青木守弘 (1972)：宮城県川渡産蛇紋岩について. 地質雑, 78, 687 -694 .

青木守弘, 船山敬子 (1982) : 阿武隈山地北縁, 丸森町南部の超塩 基性岩類. 日本地質学会学術大会講演要旨， 89, 397.

荒井章司, 久田健一郎 (1991) : 関東山地, 山中白亜系石堂層中の 砕屑性クロムスピネル，岩鉱，86, 540-553. 
Arai, S., Okamura, H., Kadoshima, K., Tnaka, C., Suzuki, K. and Ishimaru, S. (2011): Chemical characteristics of chromian spinel in plutonic rocks: implication for deep magma processes and discrimination of tectonic settings. Island Arc, 20, 125-137.

Barnes, S.J. (2000): Chromite in komatiites, II. Modification during greenschist to mid-amphibolite facies metamorphism. $J$. Petrol., 41, 387-409.

Barnes, S.J. and Roeder, P.L. (2001): The range of spinel composition in terrestrial mafic and ultramafic rocks. J. Petrol., 42, 2279-2302.

Brown, E.H. (1977): The crossite content of Ca-amphibole as a guide to pressure of metamorphism. J. Petrol., 18, 53-72.

Fabries, J. (1979): Spinel-Olivine geothermometry in peridotites from ultramafic complex. Contrib. Mineral. Petrol., 69, 329336.

Fujimaki, H and Yomogida, K. (1986a): Petrology of Hayachine ultramafic complex in contact aureole, NE Japan (I) primary and metamorphic minerals. J. Japan. Assoc. Min. Petr. Econ. Geol., 81, 1-11.

Fujimaki, H and Yomogida, K. (1986b): Petrology of Hayachine ultramafic complex in contact aureole, NE Japan (II) metamorphism and origin of the complex. J. Japan. Assoc. Min. Petr. Econ. Geol., 81, 59-66.

藤田至則, 加納 博, 滝沢文教, 八島隆一(1988)：5 万分の 1 地 質図幅「角田」及び説明書, 地質調査所.

Hiroi, Y., Yokose, M., Oba, T., Kishi, S., Nohara, T. and Yao, A. (1987): Discovery of Jurassic radiolarian from acmiterhodonite-bearing metachert of the Gosaisyo metamorphic rocks in the Abukuma terrane, northeastern Japan. J. Geol. Soc. Japan, 93, 445-448.

Hiroi, Y., Kishi, S., Nohara, T., Sato, K. and Goto, J. (1998): Cretaceous high-temperature rapid loading and unloading in the Abukuma metamorphic terrane, Japan. J. Metamorphic Geol., 16, 67-81.

猪木幸男, 滝沢文教, 片田正人 (1972) : 金華山の地質構造にまつ わる若干の問題. 地球科学, 26, 139-150.

Ishiwatari, A. (1985a): Granulite facies metacumulates of the Yakuno Ophiolite, Japan: Evidence for unusually thick oceanic crust. J. Petrol., 26, 1-30.

Ishiwatari, A. (1985b): Igneous petrogenesis of the Yakuno ophiolite (Japan) in the context of the diversity of ophiolites. Contrib. Mineral. Petrol., 89, 155-167.

石渡 明(1989)：日本のオフィオライト. 地学雑. 98, 104-117.

加納 博, 黑田吉益, 宇留野勝敏, 濡木輝一, 蟹沢聰史, 丸山孝 彦, 梅村隼夫, 光川 寛, 瀬戸延男, 大平芳久, 佐藤 茂, 一色直記 (1973)：地域地質研究報告 5 万分の 1 図幅 竹貫地 域の地質. 地質調查所.

蟹沢聡史 (1969) : 東北地方に点在する変成岩類. 地質学論集, 4, 109-111.

北村 信 (1965)：5 万分の 1 地質図幅「焼石岳」および説明書. 地質調査所.

北村 信, 蟹沢聰史 (1971)：奥羽脊梁山脈焼石岳南麓の先第三系 基盤岩類について．東北大地質古生物研邦報，71, 61-66.

久保和也, 山元孝広 (1990)：阿武隈山地東縁原町地域の白亜紀貫 入岩類一岩石記載抢よび $\mathrm{K}-\mathrm{Ar}$ 年代一. 地質雑, 96, 731-
743.

前川寛和 (1981)：北上山地南西部母体層群の地質. 地質雑, 87, 543-554.

Minato, M., Hunahashi, M., Watanabe, J.and Kato, M. (1979): Variscan geohistory of northern Japan: the Abean orogeny. pp. 427, Tokai University Press, Tokyo, Japan.

Ohara, Y. and Ishii, T. (1998): Peridotites from southern Mariana forearc: heterogeneous fluid supply mantle wedge. Island Arc, 7, 541-558.

Okamura, H., Arai, S. and Kim, Y.-U. (2006): Petrology of forearc peridotite from the Hahajima Seamount, Izu-Bonin arc, with special reference to chemical characteristics of chromian spinel. Mineral. Mag., 70, 15-26.

Onuki, H. (1963): Petrology of the Hayachine ultramafic complex in the Kitakami Mountainland, Northern Japan. Science Report, Tohoku University, Series III, 8, 241-295.

Onuki, H. (1965): Petrochemical research on the Horoman and Miyamori ultramafic intrusives, northern Japan. Science Report, Tohoku University, Series III, 9, 217-276.

大沢 穠, 舟山裕士, 北村 信 (1971) : 地域地質研究報告 5 万分 の 1 図幅 川尻地域の地質. 地質調査所.

Ozawa, K. (1984): Geology of the Miyamori ultramafic complex in the Kitakami Mountains, Northeast Japan. J. Geol. Soc. Japan, 90, 697-716.

Ozawa, K. (1988): Ultramafic tectonite of the Miyamori ophiolitic complex in the Kitakami Mountains, Northeast Japan: Hydrous upper matle in island arc. Contrib. Mineral. Petrol., 99, 159-175.

Ozawa, K. (1994): Melting and melt segregation in the mantle wedge above a subduction zone: evidence from the chromitebearing peridotites of the Miyamori ophiolite complex, Northeastern Japan. J. Petrol., 35, 647-678.

小沢一仁, 柴田 賢, 内海 茂 (1988)：北上山地宮守超苦鉄質岩 体のはんれい岩類に含まれる角閃石 $\mathrm{K}-\mathrm{Ar}$ 年代. 岩鉱, 83, 150-159.

笹田正克 (1984)：神室山一栗駒山地域の先新第三紀基盤岩類一そ の 1 鬼首一湯沢マイロナイト帯一. 地質雑, 90, 865-874.

島津光夫 (1954a) : 北上山地西南部田河津村附近の塩基性及び超 塩基性岩 ( I ). 岩鉱, 38, 70-80.

島津光夫 (1954b) : 北上山地西南部田河津村附近の塩基性及び超 塩基性岩 (II). 岩鉱, 38, 101-109.

竹内 誠(1994)：南部北上帯下部ジュラ系志津川層群中の砕屑ザ クロ石・クロムスピネル・クロリトイドの起源. 地質雑, 100, 234-248.

滝沢文教, 一色直記, 片田正人 (1974)：地域地質研究報告 5 万分 の 1 地質図幅 金華山地域の地質．地質調査所.

土谷信之, 伊藤順一, 関 陽児, 巌谷敏光 (1997)：地域地質研究 報告 5 万分の 1 地質図幅 岩ヶ㠃地域の地質. 地質調査所.

Uchino, T. and Kawamura, M. (2010): Tectonics of an Early Carboniferous forearc inferred from high- $\mathrm{P} / \mathrm{T}$ schist-bearing conglomerate in the Nedamo terrane, Notheast Japan. Island Arc, 19, 177-191.

八島隆一, 中通り団体研究会 (1982) : 中通り・川桁地域の変成岩 類 (II) 一奥羽脊梁山脈南部地域の変成岩類と超苦鉄質岩類 一. 福島大学理科報告, 32, 59-75. 